
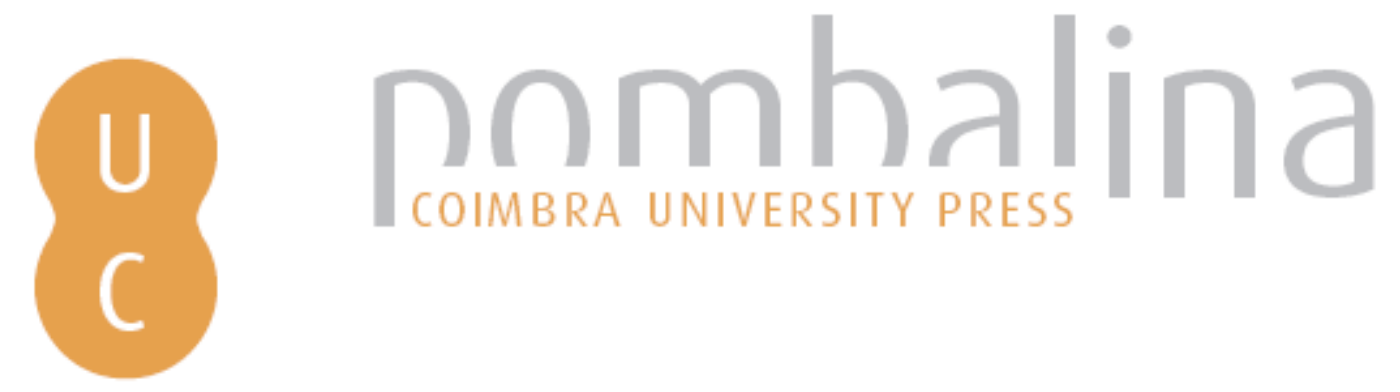

\title{
The urban side of the wildland-urban interface: a new fire audience identified following an extreme wildfire event in Aotearoa/New Zealand
}

\author{
Autor(es): $\quad$ Langer, E. R. (Lisa); Pearce, H. Grant; Wegner, Simon
}

Publicado por: Imprensa da Universidade de Coimbra

URL

persistente: URI:http://hdl.handle.net/10316.2/44612

DOI: $\quad$ DOI:https://doi.org/10.14195/978-989-26-16-506_95

Accessed : $\quad$ 26-Apr-2023 06:27:30

A navegação consulta e descarregamento dos títulos inseridos nas Bibliotecas Digitais UC Digitalis, UC Pombalina e UC Impactum, pressupõem a aceitação plena e sem reservas dos Termos e Condições de Uso destas Bibliotecas Digitais, disponíveis em https://digitalis.uc.pt/pt-pt/termos.

Conforme exposto nos referidos Termos e Condições de Uso, o descarregamento de títulos de acesso restrito requer uma licença válida de autorização devendo o utilizador aceder ao(s) documento(s) a partir de um endereço de IP da instituição detentora da supramencionada licença.

Ao utilizador é apenas permitido o descarregamento para uso pessoal, pelo que o emprego do(s) título(s) descarregado(s) para outro fim, designadamente comercial, carece de autorização do respetivo autor ou editor da obra.

Na medida em que todas as obras da UC Digitalis se encontram protegidas pelo Código do Direito de Autor e Direitos Conexos e demais legislação aplicável, toda a cópia, parcial ou total, deste documento, nos casos em que é legalmente admitida, deverá conter ou fazer-se acompanhar por este aviso.

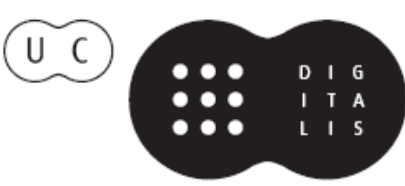




\section{ADVANCES IN}

\section{FOREST FIRE RESEARCH}

\section{8}

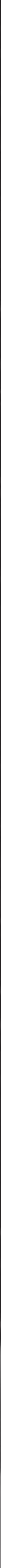




\title{
The urban side of the Wildland-urban interface - a new fire audience identified following an extreme wildfire event in Aotearoa/New Zealand
}

\author{
E.R. (Lisa) Langer ${ }^{1 *}$; H. Grant Pearce ${ }^{1}$; Simon Wegner $^{3}$ \\ ${ }^{1}$ Scion. PO Box 29 237, Christchurch 8440, New Zealand, \{lisa.langer@scionresearch.com*, \\ grant.pearce@scionresearch.com\} \\ ${ }^{3}$ Scion, Private Bag 3020, Rotorua 3046, New Zealand, \{simon.wegner@scionresearch.com\}
}

\begin{abstract}
Wildland-urban interface wildfires are increasingly impacting communities worldwide. In New Zealand this has been demonstrated by the destruction or damage of over 25 homes during the 2016-2017 fire season, the greatest number lost in 100 years. The wildfire which most impacted these statistics is the Port Hills fire, which resulted in the loss of nine houses and the evacuation of over 1400 residents on the margin of the city of Christchurch in February 2017. This wildfire opens the door to a new focus of attention required to address wildfire mitigation needs of suburban properties in the urban fringe in wildfire prone areas.

Although mitigation measures for large and small rural properties are well understood by fire officials and conveyed to property owners, uptake has been minimal in the dense suburban communities which extend into the WUI. Suburban property owners in the urban fringe will require greater focus by fire managers to ensure residents are aware of the risk of wildfires, and adequately prepared to face the risk of potentially devastating wildfires in the future. However, these communities are not merely denser versions of their rural neighbours and lessons from other parts of the WUI may not apply. Engaging with them will necessitate understanding their differences and developing new messages appropriate to their context.
\end{abstract}

Keywords: urban fringe, risk awareness, mitigation, preparedness

\section{Background}

Frequent small, and occasional large, wildfires occur in New Zealand (about 4100 wildfires were recorded burning approximately 4170 ha per year from 2005-06 to 2014-15; National Rural Fire Authority data 2015). The majority of these wildfires are caused by human activity (Anderson et al. 2008). However, the impact of wildfire events on communities in the wildland-urban interface (WUI, or rural-urban interface (RUI) as it is more commonly referred to in New Zealand) has grown in recent years with over 25 homes destroyed throughout country during the 2016-2017 fire season, the greatest number lost in 100 years (AFAC 2017).

The WUI generally is defined as areas where houses mix or intermingle with potentially flammable vegetation, such as where buildings are in close proximity to large contiguous patches of flammable vegetation (interface) and where buildings are interspersed within flammable vegetation (intermix) (Radeloff et al. 2005). However, properties impacted by WUI wildfires are not just those surrounded by rural land, but include those that lie within suburbs, with either one boundary bordered by rural land or completely within the city limits, on the margins of urban areas or what is often referred to as the urban fringe.

There is an increasing worldwide trend of wildfires impinging on the margins of suburban areas of cities with an associated increasing risk to lives and property (for example, Hobart, Australia, 1967; Canberra, Australia, 2003; and Fort McMurray, Canada, 2016). Similarly wildfire events on the margins of urban areas are not new to New Zealand (Fogarty, 1997; Graham and Langer 2009; Hart and Langer 2014), but up until 2017 they were relatively infrequent and few properties were destroyed 
or fatalities experienced. This changed in February 2017, however, when a large wildfire occurred on the Port Hills, adjoining the city of Christchurch in the South Island, significantly adding to the tally of destruction experienced during the 2016/17 fire season. Although regarded as a moderately small wildfire in international terms, the Port Hills wildfire is considered one of the biggest and most severe in recent New Zealand history, bringing with it new wildfire management and community preparedness concerns.

Research in New Zealand to date has focused on wildfire-affected rural and WUI communities, including lifestyle ${ }^{1}$ block owners, from a rural perspective. That is, the WUI has largely been characterised as areas where formerly urban residents' have relocated into rural spaces. These new lifestyle block properties may be clustered together, but generally retain the low density and character of an otherwise rural landscape. Effectively, a wildfire impacts a single property and then may spread to neighbouring lifestyle properties. Therefore, while their owners represent a different audience, the fire landscape and the messages fire officials wish to convey are largely unchanged.

Fires on the margins of cities, however, bring residents from suburban properties into the spot light. Although they may be adjacent to areas with lifestyle blocks, denser suburban developments on previously undeveloped land have an entirely different character, essentially transforming pockets of space from rural to urban. A single wildfire can impact on multiple properties at once, and even spread from structure to structure within the suburban area.

Suburban residents represent an entirely different audience as well as a different landscape, changing the nature of their threat and range of preparation options at hand. This will require a shift in fire management, supported by research to ensure that they too have adequate awareness of the risk of future wildfires that could impact them and prepare their properties accordingly.

\section{Methodology}

This paper considers the Port Hills wildfire event on the margin of Christchurch in February 2017 and highlights impacts on local residents living in the denser suburban areas of the WUI. Drawing on ongoing research into the fire and its aftermath, it discusses the changing nature of the wildfire threat in New Zealand and the implications these changes have for communities, for fire and land managers and, consequently, for researchers.

International and national reporting of wildfires that have affected communities on the fringe of urban areas, community audiences and their risk awareness and preparedness have been evaluated to set the context for this think piece.

\section{Port Hills fire event}

The Port Hills wildfire occurred on the fringe of urban areas of Christchurch city and burned 1660 ha of largely ungrazed grass, conifer plantations, pockets of native forest, and regenerating native and exotic scrub vegetation, within a perimeter of $60 \mathrm{~km}$ (see Figure 1). The wildfire began as two separate fires on 13 February 2017, starting within two hours of each other in different areas of the Port Hills and then joining two days later to become an extreme wildfire event. A state of emergency was

\footnotetext{
${ }^{1}$ A lifestyle property is a New Zealand term introduced by real estate agents in the 1980's to describe rural small holdings purchased by people who want to live a rural lifestyle, often with a small number of farm animals or other agricultural activities, but who derive their principal income from non-farming activities (Paterson, 2005).
} 
declared to support emergency services, and the fire was not officially considered to have been extinguished for 66 days (AFAC 2017).

The fire resulted in the loss of nine homes and fire damage to five others on small lifestyle properties surrounded by rural land. The wildfire caused the evacuation of about 450 households (estimated over 1400 residents) for 3-9 days. Significant loss or threat also occurred to infrastructure, including major power lines, airport radar, communications networks, radio and television transmission towers, and a mountain-bike and recreational facility. Tragically, a helicopter pilot was killed in an accident while fighting the fire. Although most devastation was experienced by those living on lifestyle properties, the majority of threatened households lay on small properties of less than $1000 \mathrm{~m}^{2}$ within suburban areas and had either one boundary bordered by rural land or were completely within the city limits.

The Port Hills, with moderate to steep ridges and gullies and slopes up to 30 degrees, and a range of flammable fuel types including particularly sprayed gorse (Ulex europaeus) and cured rank grass, had fire behaviour potential which ranged between high and extreme. Thus, the area exhibited a particular susceptibility to wildfire events at this time of the summer and a total fire ban was in place.

At the time of this wildfire event, rural fire control was the responsibility of Rural Fire Authorities, comprising local territorial authorities (district and city councils), the Department of Conservation, and Defence and forestry-based Rural Fire Districts. Four months later, on 1 July 2017, the urban and rural fire agencies were merged into the single Fire and Emergency New Zealand organisation.

The cause of both wildfires ignitions remains undetermined, but the post-fire investigation believed them to have been suspicious. Based on the information available, Fire and Emergency New Zealand believe the first ignition to have been deliberately lit, and the second either accidental or deliberately lit (FENZ, 2017).

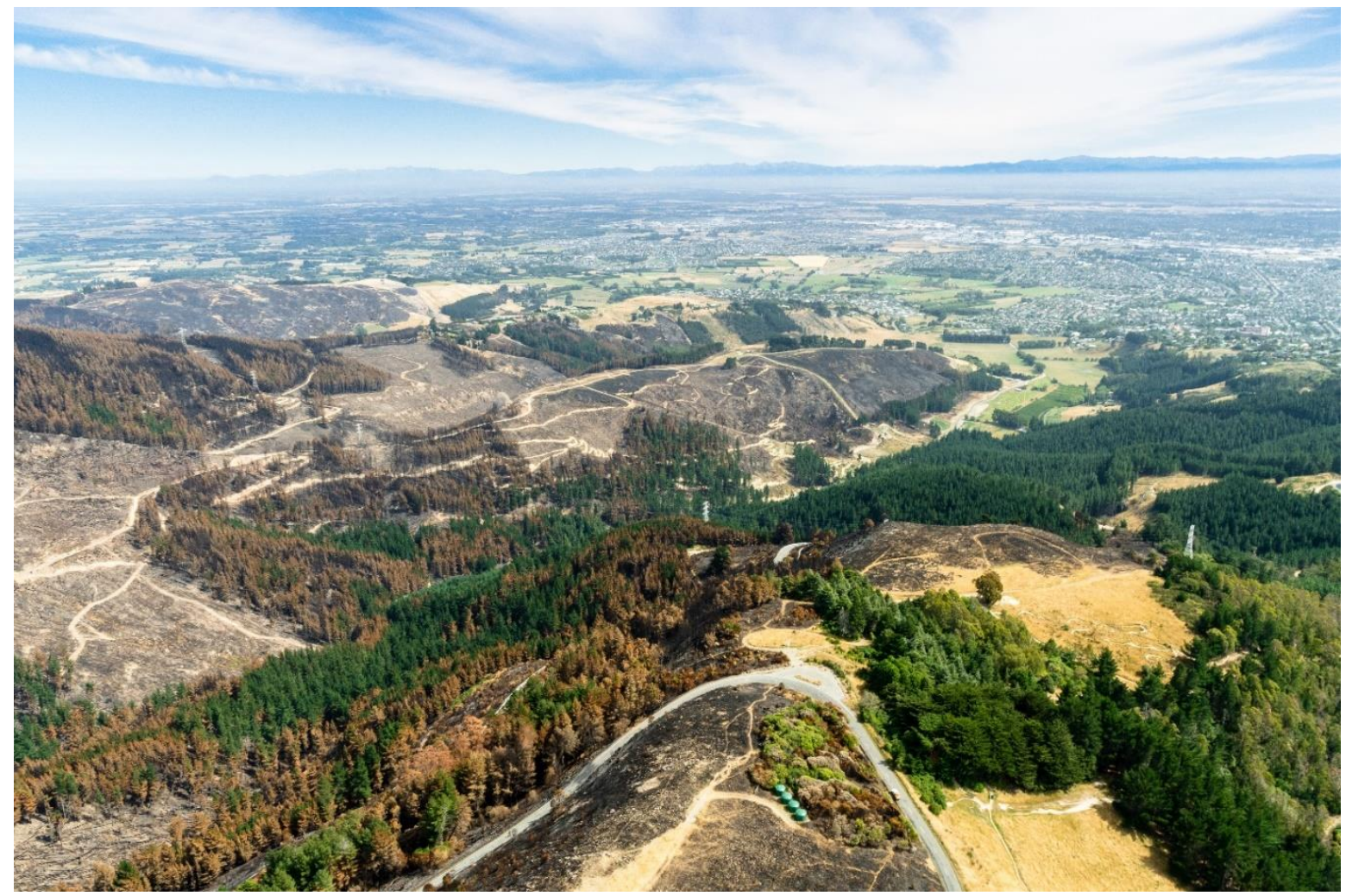

Figure 1 - Aerial view of the wildfire which occurred on the Port Hills, adjoining Christchurch, burning 1660 ha of farmland, plantation and native forest and recreational areas, destroying nine homes and damaging a further five, and causing the evacuation of about 450 households within a perimeter of $60 \mathrm{~km}$ in February 2017 (V. Clifford, Scion). 


\section{Drivers of change leading to increased wildfire risk}

Though fires on the margins of urban areas in New Zealand have been relatively rare in the past, they are likely to become more common. Climate change modelling predicts that New Zealand will become hotter and drier, creating conditions that increase both the frequency and severity of wildfire events (Pearce et al. 2005; Pearce and Clifford 2008; Pearce et al. 2011). With the overall risk of wildfire expected to increase, so too is the likelihood that these fires will occur within the WUI (Reisinger et al. 2014).

The increased risk associated with changing climate is compounded by a changing landscape. As is common worldwide, the area of New Zealand encompassed by the WUI and the number of people living and recreating within that zone are growing (Bayley and Goodyear 2004). Andrew and Dymond (2012) estimated that 5800 new lifestyle blocks have been added annually since 1998. Not only does this mean that more people are exposed to wildfire risk, the growing number of people and homes also increases the costs of fire suppression (Gude et al. 2013) and introduces more opportunities for humancaused wildfires to occur (Radeloff et al. 2018), through accidental ignition sources such as mower blade strikes, recreational fires and fireworks, escaped rubbish burns or electrical infrastructure faults as well as through intentional arson. Additionally, many new WUI residents will have little knowledge about fire risks or experience with fire use, so will pose greater individual risk of starting accidental wildfires than previous rural residents (Jakes et al. 2010; Hart and Langer 2014).

At the same time, in some parts of New Zealand, land near the WUI that was formerly grazed pasture is being retired from production and used instead for conservation or recreation purposes. Often, this results in rising fuel loads as grasses are slowly replaced by woody shrubs and native bush. The combined impacts of these changes are already becoming apparent in a recent increase in WUI fire incidents and increased number of homes threatened, damaged or lost (Pearce unpubl. data).

\section{WUI in New Zealand}

\subsection{Audiences, risk awareness and preparedness}

Turning to the literature, we are informed that not all residents have the same level of fire experience, fire risk awareness or preparedness. Internationally, research has demonstrated that residents living in high-risk areas (McCaffrey et al. 2013, 2015) or where a recent wildfire has occurred (McGee et al. 2009; Champ and Brenkert-Smith 2016) are more likely to be aware of wildfire risk. Research in New Zealand has identified similar differences in awareness between and within communities. Those with greater experience of rural living, or of wildfire, have been found to be more aware of wildfire risk and more likely to take preventative action (Jakes and Langer 2012; Langer and Hart 2014; Langer and McGee 2017; Nicholas and Hepi 2017). For example, in a study of a wildfireaffected peri-urban community in Canterbury, newcomers with shorter residency were found to have less awareness of wildfire risk and preparedness than longer-term residents (Jakes et al. 2010). Likewise, drawing on three case studies in wildfire-prone areas across New Zealand, Hart and Langer (2014) found varying knowledge of wildfire risk, fire restrictions and preparedness measures between long-term rural or semi-rural fire users and non-resident land owners or suburban dwellers who had less fire experience and did not use fire.

It is becoming increasingly clear, however, that there can also be significant variations in how people perceive and act upon wildfire risks. While experience with wildfire is associated with increased risk awareness in the short term, the connection is not universal and does not always lead to preventative or mitigative action. In an American study, for example, Olsen et al. (2017) found that WUI residents' perceptions of wildfire risk had little impact on levels of preparedness.

Much of the variation may be because of differences in how people interpret and act upon their perceptions of wildfire risk (Paveglio and Edgeley, 2017; Sword-Daniels et al. 2018). Though the

Advances in Forest Fire Research 2018 - Page 862 
literature typically treats geographic communities as homogenous units with shared perspectives and experiences, differences between socio-economic, cultural and demographic sub-communities can have profound impacts on how they interpret fire experience and risk (Paveglio and Edgeley 2017; Hart and Langer unpubl. data). For example, Langer and Hart (2014) described how, in a community that had recently been affected by wildfires, town dwellers who had witnessed wildfire nearby tended to have seen it as a spectacle rather than a threat and, therefore, showed little appreciation of risk to their home or person and tended not to take mitigative action. On an individual level, values, identities, lived experiences and other psycho-social factors shape how people interpret risks and decide how to act (Sword-Daniels et al. 2018). An exploratory study of media and social media during and after the Port Hills fire, has already identified significant differences in how people made sense of the fires in the context of underlying socio-political debates and where people believe responsibility for action lies (Langer and Wegner unpubl. data). Further research will be necessary to fully understand the impact that these fires have had.

However, the expanding WUI brings added social challenges beyond simply introducing another, different audience. As WUI communities grow in population, the potential complexities within them become even greater. Moreover, because a high proportion of the growth is in developments on previously undeveloped land, they may lack any form of community per se. There is also potential for conflict between new WUI residents and longer-term, previously rural residents who have experienced the landscape and community around them changing (Curran-Cournane et al. 2016). These considerations have been missing from the New Zealand literature and is underdeveloped internationally. Thus, research will be needed to better understand the more urban populations and communities living within the WUI and how they might differ from previous conceptions of communities at risk from wildfire.

\subsection{Mitigation}

Although there is well-established literature discussing mitigation options for landowners to reduce the likelihood and impact of wildfires (e.g. Cohen, 2000; Mell et al. 2010), this has not translated into significant mitigation in developing WUI areas of New Zealand.

Fire and land management agencies throughout the world recognise both wildfire risk and appropriate mitigation options (e.g. Cohen, 2000; Calkin et al. 2014). The necessity of having planning restrictions in place to ensure appropriate house siting and the use of fire-resistant construction materials for buildings, and increased homeowner awareness and education to encourage fire risk mitigation activities properties, such the management of fuels and maintenance of 'defensible (or defendable) space'1 (Syphard et al. 2014; Kornakova and March, 2017) are well recognised by fire managers.

Worldwide, people choose to live in wildfire prone areas and often do not fully understand the severity of wildfire risk (relative to other risks). The lack of awareness is demonstrated by the fact that limited mitigation measures are put in place by residents on their individual properties, collectively with their neighbourhoods, or in partnership with fire and other land management agencies (e.g.

${ }^{1}$ The concept of a defensible space is to remove or reduce the amount of flammable vegetation within a zone of at least 10-30 m wide (and preferably greater, where space permits) around the home which can limit fire spread and flame contact, and reduce radiated heat, and thereby increasing the chances of house survival (Wilson and Ferguson 1986; Cohen 2000). Regular maintenance to remove the build-up of dead material, including in roof gutters where leaf litter can provide a potential ignition point for windblown embers is the key to a successful defensible space. Low flammability species also can significantly reduce fire spread and intensity. 
Toman et al. 2013; McCaffrey 2015) and homes and lives continue to be lost in WUI fires. Successful community programmes have been adopted in North America and South Africa (such as the US FireWise and the Canadian FireSmart programmes (Haynes and Madsen 2017; Partners in Protection 1999) and, more broadly, the Fire Adapted Communities Learning Network (Anon. 2014)). However, in New Zealand, the National Rural Fire Authority's FireSmart programme (NRFA 2009) has struggled to get traction (Hart and Langer 2014; Pearce et al. 2014).

To date planning and wildfire messages to encourage mitigation by residents in the WUI has focused on rural and lifestyle properties. However, the Port Hills fire, and those that have preceded it that have either damaged or threated suburban properties in the urban fringe, identifies a new audience that needs to be considered. It also raises the question of whether instructions and target audiences need to be broadened and modified to suit different properties. For example, a defensible space of 10$30 \mathrm{~m}$ may be hard to implement on smaller suburban properties.

\section{Discussion}

The devastating 2017 Port Hills wildfire, and other similar WUI fire incidents from the past fire season, must serve as a major impetus to New Zealand fire agencies and property owners alike to raise awareness of the WUI fire issue, and increase education and guidance to at-risk communities on options for mitigating wildfire risk. Just as importantly, they should also prompt a significant review of the treatment of wildfire risk in local planning processes across the country, including improved identification of wildfire prone areas, and development of stronger requirements around development, construction and provision of defensible space in these high wildfire risk areas.

The risk of WUI wildfires like the Port Hills wildfire is not new. Similar wildfires have been reported widely over the years, both internationally (Butler 1974; Gale and Cortner 1987) and in New Zealand (Anon. 1982, FRFANZ 1994). The Port Hills wildfire, which resulted in the greatest reported property loss in an individual fire in almost 100 years, and followed a number of other WUI fires during the same fire season, serves as a wakeup call to fire and land managers. It provides a window into the future for New Zealand, with the likelihood of many similar wildfire events in the WUI impacting on communities, intensified by climate change, changing land use and the development of further subdivisions in the urban fringe of cities. Although affected communities are likely to have heightened awareness for the following wildfire season if dry conditions prevail, this is unlikely to be translated into increased mitigation by households, neighbourhoods and communities to reduce the longer term prospect of adverse impacts in the future. This step will not occur without considerable guidance and continued input from agencies-guidance which has been adapted to suit the specific audience.

The Port Hills wildfire has identified a new audience that will require special consideration by fire and land managers to ensure suburban residents in the urban fringe are aware of the risk wildfires could pose and adequately prepared for likely future disasters.

Fire and land management agencies have the responsibility to reduce the probability of home exposure to wildfire, through fire prevention measures (such as fire season restrictions and activity controls) that reduce the prospect of future wildfires events, and also readiness and response activities to suppress wildfires when they do occur. The management of fuels can also help reduce the chances of fire spread, decrease potential fire intensity, and hence increase the likelihood of successful fire suppression. Significant WUI fires such as the recent Port Hills wildfire clearly show that not all fires can be prevented, or controlled before they adversely impact people and property. This highlights the necessity for local government to ensure appropriate local planning and land use zoning controls to reduce exposure to wildfires.

In New Zealand, FireSmart community fire protection initiatives led by the National Rural Fire Authority/NZ Fire Service (NRFA 2004, 2009) have struggled to gain traction (Hart and Langer 2014)

Advances in Forest Fire Research 2018 - Page 864 
and perceived wildfire risk is considered to be a low priority compared to other hazards, such as flooding or earthquakes. It is essential that planners give greater recognition to wildfire risk, particularly in wildfire prone regions, and convert this into local planning processes. Glavovic (2010) and others (e.g. Saunders and Kilvington 2016, Crawford et al. 2018) have clearly articulated the benefits of natural hazards planning in New Zealand, and identified the barriers and priority actions required to realise the potential for disaster risk reduction. Key to achieving this is the strengthening of links between planners and emergency managers (Saunders et al. 2007), and also engaging and involving communities in the planning process. The latter is by no means an easy task, but initiatives such as Community Wildfire Protection Plans (CWPPs) have been found to be very successful in the U.S. (Jakes and Sturtevant 2013). However, this requires an understanding of the make-up of communities (Carroll and Paveglio 2016; Hart and Langer, unpubl. data) and what they value (Beilin and Reid 2015; Rawluk et al. 2017).

An onus remains on homeowners to take some responsibility for protecting their property from wildfires (Calkin et al. 2014) with or without specific local government wildfire risk planning requirements or community-led fire risk reduction initiatives, However, observance of planning requirements will not prevent all homes from being destroyed. Similarly, fire agencies cannot protect every property during a major event.

Research to date highlights clear differences in wildfire risk awareness and preparedness actions by urban and rural residents. In tandem with this, it illustrates complexities and divisions within communities that influence how people make sense of wildfire experiences (McCaffery 2015; Jakes and Langer 2012; Langer and McGee 2017). Opposing understandings of responsibility may help to explain the difficulty that fire experts face in promoting community action and, in particular, the poor correlation between people being aware of risks from wildfire and taking actions to mitigate those risks. The connection between awareness and taking actions to mitigate risk may well depend on where the ownership of risk and responsibility is seen to lie (Hart and Langer 2014; Langer and Wegner unpubl. Data). Hart and Langer (unpubl. data) have demonstrated the need for fire managers to proactively work with sectors of communities on an individual basis to build the community preparedness for future wildfire events.

This discussion paper paves the way for an in-depth study of the community affected by the 2017 Port Hills fire to gain a better understanding of wildfire awareness and preparedness of residents living in suburban properties in the urban fringe. This identified new audience will require special consideration by fire and land managers to ensure residents are aware of the risks wildfires could pose and adequately prepared for likely future disasters. Proposed research by the authors will advance knowledge to determine whether the recent experience of those living in the urban fringe has changed their awareness of wildfire risk, and whether the ways that residents interpret their experiences and the social norms surrounding loss may inhibit change.

\section{Conclusion}

With the growing number of people living in the WUI, and the number and severity of wildfires in the WUI expected to increase, the Port Hills fire of February 2017 serves as a clear indication to New Zealand communities of the likely wildfire threats to come. The fire signals that the changes ahead are not merely an increase in the risk to people at the fringe, but represent a change in the nature of the audience and landscape at risk. Previous work has focussed on the rural side of the WUI, with management efforts targeted at that context. However, denser pockets of the urban fringe, often recently developed and populated by urban residents, have not been well incorporated into the existing New Zealand wildfire literature or into fire managers' risk mitigation messaging. These areas will require special consideration in terms of the different audiences found within, and the different awareness and preparation messages they will require. 


\section{Acknowledgments}

Funding for this work was provided by New Zealand's Ministry of Business Innovation and Employment through Resilience to Nature's Challenges National Science Challenge and the Endeavour fund via contract C04X1602, 'Preparing New Zealand for Extreme Fire'.

\section{References}

AFAC (2017) Independent Operational Review: A review of the management of the Port Hills fires in February 2017. Report Prepared for Fire and Emergency New Zealand. https://fireandemergency.nz/assets/Documents/Files/AFAC-Port-Hills-Review.pdf

Anderson SAJ, Doherty J, Pearce HG (2008) Wildfires in New Zealand from 1991 to 2007. New Zealand Journal of Forestry 53, 19-22.

Andrew, R, Dymond, JR (2012) Expansion of lifestyle blocks and urban areas into high-class land: an update for planning and policy. Journal of the Royal Society of New Zealand 43(3), 128-140.

Anon. (2014) The National Strategy: The Final Phase in the Development of the National Cohesive Wildland Fire Management Strategy. Available at https://www.forestsandrangelands.gov/strategy/documents/strategy/CSPhaseIIINationalStrategyA pr2014.pdf

Bayley A, Goodyear R (2004) 'New Zealand: an Urban/Rural Profile.' (Statistics New Zealand: Wellington, NZ)

Butler, CP (1974) The urban/wildland fire interface. In 'Proceedings of Western States Section, 6-7 May 1974, Spokane, Washington' (Washington State University: Pullman, WA) Combustion Institute Papers, 74(15), 1-17.

Calkin DE, Cohen JD, Finney MA, Thompson MP (2014) How risk management can prevent future wildfire disasters in the wildland-urban interface. Proceedings of the National Academy of Sciences of the United States of America 111, 746-751.

Calkin DE, Rieck JD, Hyde KD, Kaiden JD (2011) Built structure identification in wildland fire decision support. International Journal of Wildland Fire 20, 78-90.

Carroll M, Paveglio T (2016) Using community archetypes to better understand differential community adaptation to wildfire risk. Philosophical Transactions of the Royal Society B 371, 20150344.

Champ PA, Brenkert-Smith H (2016) Is seeing believing? Perceptions of wildfire risk over time. Risk Analysis 36, 816-830.

Cohen JD (2000) Preventing disaster: home ignitability in the wildland-urban interface. Journal of Forestry 98, 15-21.

Curran-Cournane F, Cain T, Greenhalgh S, Samarsinghe O (2016) Attitudes of a farming community towards urban growth and rural fragmentation-An Auckland case study. Land Use Policy 58, 241250.

Fire and Emergency New Zealand (2017) Fire and Emergency New Zealand releases findings of the Cause and Origin of Port Hills fires. Fire and Emergency New Zealand press release, 3 November 2017. Available at https://fireandemergency.nz/assets/Documents/Files/Port-Hills-Cause-andOrigin.pdf

Fogarty L (1995) Creating less fire prone environments - an example from the gorse covered hills of Wellington and the Hutt Valley. In 'Proceedings, Forest and Rural Fire Association of New Zealand (FRFANZ) 5th Annual Conference, 2-4 August 1994, Nelson’ pp 135-151 (FRFANZ: Rotorua, $\mathrm{NZ)}$ 
Gale RD, Cortner HJ (Eds) (1987) 'People and Fire at the Wildland/Urban Interface: A Sourcebook'. (USDA Forest Service: Washington, DC)

Graham R, Langer ER (2009) Lessons Learned: Wither Hills Fire, Blenheim, December 2000. Scion Client Report No. 16183 (Christchurch, NZ)

Gude PH, Jones K, Rasker R, Greenwood MC (2013) Evidence for the effect of homes on wildfire suppression costs. International Journal of Wildland Fire 22, 537-548.

Hart M, Langer ER (2014) Effective communication: communities and wildfire in New Zealand. Contract report to Bushfire Cooperative Research Centre. Scion Client Report No. 21017. (Christchurch, NZ)

Haynes H, Madsen R (2017) Wildland/Urban Interface: Fire Department Wildfire Preparedness and Readiness Capabilities - Final Report, National Fire Protection Association, January 2017. Available at http://www.nfpa.org//-/media/Files/News-and-Research/Fire-statistics/Fireservice/osWUI2017.pdf

Jakes PJ, Kelly L, Langer ER (2010) An exploration of a fire-affected community undergoing change in New Zealand. The Australian Journal of Emergency Management 25, 48-53.

Jakes P, Langer ER (2012) The adaptive capacity of New Zealand communities to wildfire. International Journal of Wildland Fire 21, 764-772. doi:10.1071/WF11086

Jakes PJ, Sturtevant V (2013) Trial by fire: community wildfire protection plans put to the test. International Journal of Wildland Fire 22, 1134-1143.

Langer ER, Hart M (2014) Effective communication of wildfire messages for New Zealand communities. Fire Technology Transfer Note 43 (Scion: Christchurch, NZ)

Langer ER, McGee TK (2017) Indigenous and non-Indigenous rural residents' wildfire risk awareness and safe use of fire on the Karikari Peninsula, Aotearoa New Zealand. International Journal Wildland Fire 26(9), 820-828. doi:10.1071/WF16133

McCaffrey S (2004) "Thinking of wildfire as a natural hazard." Society \& Natural Resources 17 (6):509-516. doi: 10.1080/08941920490452445

McCaffrey S (2015) Community Wildfire Preparedness: a Global State-of-the-Knowledge Summary of Social Science Research. Current Forestry Report 1: 81. https://doi.org/10.1007/s40725-0150015-7

McCaffrey S, Toman E, Stidham M, Shindler B (2013) Social science research related to wildfire management: an overview of recent findings and future research needs. International Journal of Wildland Fire 22, 15-24. doi:10.1071/WF11115

McCaffrey S, Toman E, Stidham M, Shindler B (2015) Social science findings in the United States. In 'Wildfire hazards, risks, and disasters'. (Eds D. Paton, J. F. Shroder) pp. 15-34. (Elsevier: Amsterdam, Netherlands)

McGee TK, McFarlane BL, Varghese J (2009) An examination of the influence of hazard experience on wildfire risk perceptions and adoption of mitigation measures. Society \& Natural Resources 22, 308-323. doi:10.1080/08941920801910765

Mell WE, Manzello SL, Maranghides A, Butry D, Rehm RG (2010) The wildland-urban interface fire problem - current approaches and research needs. International Journal of Wildland Fire 19, 238251.

NRFA (2004) 'FireSmart: Partners in Protection - Protecting our Communities from Interface Fire.' (National Rural Fire Authority: Wellington, NZ)

NRFA (2009) 'FireSmart: Home Owners Manual - Protecting Your Home from Interface Fire', 2nd edn. (National Rural Fire Authority: Wellington, NZ) 
Nicholas G, Hepi M (2017) Engaging Owners of Lifestyle Blocks in Understanding and Mitigating Wildfire Risks. Fire and Emergency New Zealand Research Report No.157. (Wellington, New Zealand)

Officials' Committee for Domestic and External Security Coordination (2007) National Hazardscape Report. (Wellington, NZ)

Oliver C (1994) Wildland Urban Interface: other perspectives. In 'Proceedings, Forest and Rural Fire Association of New Zealand (FRFANZ) 4th Annual Conference, August 3-5, 1994, Rotorua' (FRFANZ: Rotorua, NZ)

Olsen CS, Kline JD, Ager AA, Olsen, KA, Short KC (2017) Examining the influence of biophysical conditions on wildland-urban interface homeowners' wildfire risk mitigation activities in fire-prone landscapes. Ecology and Society 22(1), 21.

Partners in Protection (1999) 'FireSmart: protecting your community from wildfire' (Partners in Protection: Edmonton, Canada)

Paterson J (2005) What is a lifestyle block and is it a form of rural gentrification? A paper presented to the Waikato Branch of the Geographical Society, The University of Waikato. (Hamilton, NZ)

Paveglio TB, Edgeley C (2017) Community diversity and hazard events: understanding the evolution of local approaches to wildfire. Natural Hazards 87(2), 1083-1108. doi:10.1007/s11069-017-2810$\underline{\mathrm{X}}$

Pearce HG, Clifford V (2008) Fire weather and climate of New Zealand. New Zealand Journal of Forestry 53(3), 13-18.

Pearce HG, Kerr J, Clark A, Mullan B, Ackerley D, Carey-Smith T, Yang E (2011) Improved estimates of the effect of climate change on NZ fire danger. MAF Technical Paper No. 2011/13.

Pearce HG, Mullan AB, Salinger MJ, Opperman TW, Woods D, Moore JR (2005) Impact of climate change on long-term fire danger. New Zealand Fire Service Commission Research Report 50, National Institute of Water \& Atmospheric Research Limited.

Radeloff VC, Hammer RB, Stewart SI, Fried JS, Holcomb SS, McKeefry JF (2005) The wildlandurban interface in the United States. Ecological Applications 15(3), 799-805.

Radeloff V, Helmers DP, Kramer HA, Mockrin MH, Alexandre PM, Bar-Massada A, Butsic V, Hawbaker T, Martinuzzi S, Syphard AD, Stewart S (2018) Rapid growth of the US wildland-urban interface increases wildfire risk. Proceedings of the National Academy of Sciences of the United States of America 115, 3314-3319.

Reisinger A, Kitching R, Chiew F, Hughes L, Newton P, Schuster SS, Tait A, Whetton P (2014) Chapter 25: Australasia. In Climate Change 2014: Impacts, Adaptation and Vulnerability Contribution of Working Group II to the Fifth Assessment Report of the Intergovernmental Panel on Climate Change. (Eds VR Barros, DJ Dokken, CB Field, MD Mastrandrea, KJ Mach, TE Bilir, M Chetterjee, KL Ebi, YO Estrada, RC Genova, B Girma, ES Kissel, AN Levy, S MacCracken, PR Mastrandrea, LL White), pp. 1371-1438. (Cambridge University Press: Cambridge and New York)

Sword-Daniels V, Eriksen C, Hudson-Doyle EE, Alaniz R, Adler C, Schenk T, Vallance S (2016) Embodied uncertainty: living with complexity and natural hazards. Journal of Risk Research 21(3), 290-307.

Syphard AD, Brennan TJ, Keeley JE (2014) The role of defensible space for residential structure protection during wildfires. International Journal of Wildland Fire 23(8), 1165-1175.

Toman E, Stidham M, McCaffrey S, Shindler B (2013) Social science at the wildland-urban interface: a compendium of research results to create fire-adapted communities. General Technical Report NRS-111 (USDA, Forest Service, Northern Research Station: Newtown Square, PA) 
Twigg SM (1994) Wildland Urban Interface: The Planners perspective. In 'Proceedings, Forest and Rural Fire Association of New Zealand (FRFANZ) 4th Annual Conference, August 3-5, 1994, Rotorua' (FRFANZ: Rotorua, NZ)

VBRC (2010) 2009 Victorian Bushfires Royal Commission Final Report: Summary. Parliament of Victoria, 2009 Victorian Bushfires Royal Commission (Melbourne, AUS)

Wilson AAG, Ferguson IS (1986) Predicting the probability of house survival during bushfires. Journal of Environmental Management 23, 259-270. 